IRA-International Journal of Education \& Multidisciplinary Studies

ISSN 2455-2526; Vol.04, Issue 01 (2016)

Institute of Research Advances

http://research-advances.org/index.php/IJEMS

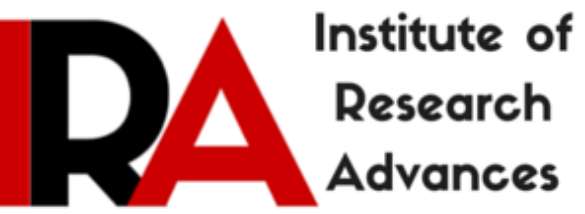

\title{
An Introduction of Scientific Survey of Francis Buchanan "Hamilton"
}

\author{
Deepali Kumari \\ Research Scholar, \\ Dept. of History \& Indian Culture, \\ Banasthali University, India.
}

DOI: http://dx.doi.org/10.21013/jems.v4.n1.p20

\section{How to cite this paper:}

Kumari, D. (2016). An Introduction of Scientific Survey of Francis Buchanan "Hamilton". IRA International Journal of Education and Multidisciplinary Studies (ISSN 2455-2526), 4(1). doi:http://dx.doi.org/10.21013/jems.v4.n1.p20

(C) Institute of Research Advances

(oc) EY-NC

This works is licensed under a Creative Commons Attribution-Non Commercial 4.0 International License subject to proper citation to the publication source of the work.

Disclaimer: The scholarly papers as reviewed and published by the Institute of Research Advances (IRA) are the views and opinions of their respective authors and are not the views or opinions of the IRA. The IRA disclaims of any harm or loss caused due to the published content to any party. 
This paper devotes an introduction of scientific survey of Francis Buchanan 'Hamilton'. Science is called the greatest triumph of the human mind over nature. Natural sciences focused attention on the investigation of the Indian environment and even placed Indians themselves towards scrutiny \& their will themselves never be any great enthusiasm for belonging to a society which is not going forward, our culture is full of unformulated rules of conventional behaviour, and we have placed a perfectly absurd value on the ability to confirm to those rules \& thus to preserve the whole system whose behaviour they are supposed to regulate. Just like that a Scottish physician Buchanan 'Hamilton' recognised for making significant contributions as a Geographer, zoologist, Botanist \& as a historian while living in India.

East India company was interested to know about India and Indian people so they appointed some surveyor and informers to give knowledge regarding India, Buchanan was one of them whom company had appointed to give further information related to India, its people their society, agriculture, religion, mineral, mines and many more.

Buchanan was appointed as a surgeon with the East India Company. He explored Burma, Chittagong, the Andaman Island, Nepal \& North Bengal \& Bihar and made detailed survey of the Botany, geography, agriculture, economy, social information \& cultures of these areas. He was the first collector of scientific natural history specimen in Bengal. He first took a post of surgeon and in 1794; he entered in the service of east India Company as a surgeon and medical officer in Bengal. He was also appointed as a Superintendent of a botanical garden in Calcutta. Buchanan absence from dominant history of India is not a case of forgotten history but a case of researching history. It means what he searched like stone, soils, mines, minerals was not new but it may be called a research or acknowledge of the specific place with its speciality.

The term of scientism helps direct our attention to the ways in which European originated science has held a hegemonic place in science at least the first third of the nineteenth century. Buchanan's survey is very essential to various activities that his name appears on the current websites of the census of India, the archaeological survey of India \& geological survey of India. It means scientific approach for a proper evolution of socio religious conditions through observation of natural phenomena.

Buchanan was one of the first important surveyor or surgeon of East India Company. The directions given to Buchanan by the court of Directors in 1807 for his survey of eastern India Combined with those that would appear to be purely scientific or curiosity value. Buchanan was asked to report on the topography \& natural resources, plains, soils, mountains, rivers, harbours, towns \& subdivisions with air weather. survey of Buchanan have attracted considerable historical attentions and demonstrate the extent to which the company \& its servants at times sought systematically $\&$ in a self - consciously scientific way to map \& compile inventories of newly acquired territories, they were to some extent exceptional for the period. In the main company did not imitate scientific projects, but merely, tolerated its employee's private pursuits ${ }^{1}$.

Buchanan shared contemporary naturalist urges towards universal classification, \& viewed his taxonomical effort as serving both local \& transnational interest. Although practical considerations played some role in his exploration, he provided for more detail for utility- less specimens that practically required. ${ }^{2}$

Science, we have now come to understand, cannot deal with ultimate reality. It can only draw a picture of nature as seen by the human mind. ${ }^{3}$

The old idea of history mainly signifying political history is now no longer accepted by historians all over the civilised world. The scope of history has been considerably widened by the newly born sciences of archaeology and anthropology. In their synthesis of reconstruction historian have adopted two very different attitudes: that of political history \& that of cultural history. ${ }^{4}$ 
It has recently became fashionable when discussing the social influence of science to put the emphasis on earlier period of history- the geometry of the Egyptians, the astronomy of Babylonians and the ballistic problems tackled by the Renaissance mathematicians. But history is a heap of data in which one can bring to light examples to prove almost any theory one wishes and one has found a nice example only the most self confident specialist has any means of judge whether it holds water no amount of pullover about the largely hypothetical past is substitute for an analysis of the present which can checked by direct experience which can be seen in Buchanan's survey. The study of the present rather than the past relations between science and society is more essential nowadays because they have changed so considerably in recent times.

In his travels to India, Buchanan described soft red, soil material which hardened upon drying, rendering it useful as a construction material. He called this material brick stone or laterite. Buchanan's original definition referred to an iron- oxide- rich, indurate, quarry able slag-like or pisolitic alluvial horizon, developed in the soil profile. The laterite observed by Buchanan was soft enough to be cut into blocks with a knife, but upon exposure to air it quickly became hard. ${ }^{5}$

Buchanan also given information about the soil of related places he visited. During his survey in south India he has given description about "Laterite" a species of Iron clay very prevalent in India. Laterite is soil types rich in iron \& aluminium, formed in hot \& wet tropical areas. Historically, laterite was cut into brick like shapes \& used in monument building\& the monument of laterite brick stones at Anadipuram, Kerala, and India ${ }^{1}$ The properties of laterite, and its place within the widen classification of geo materials have been debated for 200 years. This commemorates where the term laterite (laterally brick rock) first described \& discussed by Dr. Buchanan Hamilton in 1807 . He advised the term to describe a naturally occurring material that once cut $\&$ allowed to harden, could be used as a building material. Buchanan has first observed the cutting of laterite bricks at a quarry at Angadipuram $\left(10^{\circ} 58^{\prime} \mathrm{N}, 76^{\circ} 13^{\prime} \mathrm{E}\right)$ in the Palghat region but latter noted that the practice was more wide spread (i.e. through out modern Kerala \& Karnataka state) ${ }^{7}$.

Not only the soil or plants Buchanan also covered fishes found in River Ganga which is important in both sense economic and social point of view. It include an important work on Indian fish species, "An account of the fishes found in the river Ganges and its branches (1822), which describes over 100 species. This shows his scientific approach as a historian.

He has also contributed on finding of new species of fishes in Gangetic water .He took extensive notes on fishes \& fisheries of the districts he survey \& incorporated them in the report which he submitted to the court of Directors of East India Company. ${ }^{8}$

Buchanan a polymath- fish collector, Burma surveyor \& former ships surgeon- far preferred employment more amenable to his botanical interest but the governor general had more pressing needs in light of criticism about his territorial acquisitions among some of the company's directors \& the English public. ${ }^{9}$

Buchanan devoted over twenty years to botanical \& natural history research in India, and his work led to the publication of a number of papers \& books on Indian Botany \& natural history. After returning to England, he spends most of his time on botany. In 1820 he wrote his friend, James Smith" what appears to me most likely to be useful to science would be to publish a commentary on the Hortus Malabaricus \& Flora Amboinesis", both being work of an earlier generation of European botanists working in India. ${ }^{10}$

The technology of textile production in medieval India was particularly well suited for the prevailing social structure. An abundant supply of labour \& craftspeople in combination with a steady internal \& export market for excellent quality textiles did not provide any economic incentives for dramatic innovations. Which, in most cases tend to be capital intensive \& labour - saving devices. The fact that there was an abundance of skilled labour in medieval India is evident from the firsthand accounts of a number of observers for instance, Babar, the founder of Mughal empire, observed in 1525 that "a good thing about Hindustan is that it has unnumbered \& endless works men of every 
kind. A hundred years later the Dutch traveller Francisco Pelsaert commented that "a job which one man would do in Holland here passes through four men's hands before it is finished. Similarly in the early nineteenth century, Francis Buchanan remarked that "In India it is seldom that attempt is made to accomplish anything by machinery that can be performed by human labour. ${ }^{11}$

The world today is most of all in need of wisdom, of that supreme knowledge or science of the supreme knowledge or science of the real which is none other than metaphysics in its traditional sense. ${ }^{12}$

Such an explanation of history set outside the understanding of process and evolutions in an extremely pluralistic Indian history as well as science and technology. Buchanan proved the saying that "The man's greatness is not in what he is, but what he makes possible."

Scientism also implies that science has the ability explain all perceivable phenomena, given enough time \& resources. Ultimately, all non- scientific explanations of the world (e.g., theology) will surrender to superior, scientific eluciadations. Once science achieved this popular assumption, it truly had displaced Christian theology, not only in terms of social authority but in terms of its recognitions as a tatalizing worldwide capable of revealing the ultimate ordering principles of nature \& humanitya recognition that theology had enjoyed in medieval Europe. ${ }^{13}$

Buchanan engaged in his naturalist pursuits long before his company employment \& continued them both on voyages away from India \& upon resettlement back to Scotland. He gave attention both to fish that had no commercial value \& to those that did. Demonstrating that he viewed the activities as part from his company duties. Buchanan was seriously nettled as he prepared to retire that the governor general refused his request to present his specimen drawing in London. He hoped his collection would maintained with the rest of his collections in the city so, after his retirement, he could reality access them while he viewed them as his own property, the government determined that the descriptions belonged to it because they had been executed during the Bengal survey. He write a letter back explaining that his drawing did little to complement his survey report \& that his offer to leave them in London derived from his effort of rendering them useful to science. In the manuscript for fishes the author railed against the governor General's actions as "one of those mean exertions of power into which a weak man thrust into high authority is liable to fall. Although he hoped to serve both the EIC \& Science Buchanan understood how one made the other possible. ${ }^{14}$

The writer Peter Gottschalk has given example of his work related to fish. "The small minnow -like fish piqued his interest because of the vivid blue stripes along its diminutive silvery sides. He gave it the species name ratio \& registered it as a member of the Cyprinus danio that would include them all. Thus he accommodated an indigenous classificatory system to the Linean. This choice reflects Buchanan's larger efforts to negotiate various discursive worlds. In another example, Buchanan included his account to Mysore survey an index that intends among other goals, to help Europeans learn the Indian world he employed. In the surviving folios of his Gangetic fish, illustrations portray each fish at the centre of a page with Latin bionomical name on one side \& the indigenous name written in both Bengali \& English transpiration on the order. On various occasions when naming a fish previously unknown to Europeans, Buchanan drew on these indigenous terms (though on at least one occasion he named a genus after a friend:_Roxburgia) overall Buchanan sought to create "names greatly more polished than the sesquipedalian compounds of the modern dealers in Greek.

It has recently been argued that a revolutions in the scientific knowledge comes about not through the accumulation of data alone but through a change in the paradigm. ${ }^{15}$ when the frame work of explanation in the hypothesis is altered or a new set of questions are posed only then can there be a breakthrough in scientific knowledge. This applies as much to history \& the social sciences. ${ }^{16}$

Within the larger context of colonialism, British naturalists \& "Scientist" played active roles in persuading colonial administrators of the potential economic \& political significance of the introduction \& application of modern western science \& Technology. India represented a vas \& 
unexplored territory for British naturalist and it held out the promise of potential careers in the emerging profession of science.

It would be erroneous to think to India has having a single scientific tradition over the millennia. India became heir to a wide variety of different oral and textual traditions, drawing upon exogenous contacts as well as indigenous roots. This plurality makes it difficult not only to characterise Indian science as a whole but also to determine the precise nature of its interaction with the form of science\& Technology emanating from the west by the late eighteenth and early nineteenth centuries. Even within what is often thought of as the 'Hindu' tradition there were several strands of scientific ideas \& practices, including a tradition of empirical, observational science (particularly developed in astronomy \& medicine) that functioned alongside \& often in tandem with, various cosmological \& astrological beliefs. ${ }^{17}$

The term biotechnology we are using at present none other than a vivid approach of Buchanan because it is a inherently knowledge-intensive and having strong infrastructure would lead to value area of agriculture's, animals, husbandry, fisheries, forestry \& medicine. Biotechnology is not a miracle solution. Before the survey of Buchanan people had no idea about some certain things they were unaware that an understanding of history of the ideas of science would illuminate the ideas themselves.

The authority that western science had come to enjoy in India by the late nineteenth century was too great to be ignored in Indian's own programmes of reform \& revitalisation. There were at least two ways in which Indian sought to come to terms with western science. One was to see it as partly fulfilling promise of Indians own antiquity while, at the same time representing a western materialism that was ultimately inferior to the spiritual and intellectual legacy of Indian religions \& philosophical tradition. ${ }^{18}$

Lastly I can say that the world is enriched by science or knowledge of nature just as it is enriched by the knowledge of archaeology, language, paintings, sculpture, music \& history. And the survey has done by Buchanan have a good collection of these all.

\section{References-}

1. Arnold, David, Science Technology \& Medicine in Colonial India, Cambridge University, Press, 2000. P, 23.

2. Peter Gottschalk, Religion, Science and Empire: Classifying Hinduism \& Islam in British India, Oxford University Press, 2012. p.179.

3. Rita singh, Aristotle's Philosophy of Science, Global vision Publishing house, Delhi, 2003.p.8.

4.Devendra kumar, rajaram Patil, Cultural History from the Vayu Puran, Motilal Banarasidas, Delhi, 1973, p.2.

5. Randall, J. Schaetzl, Sharon Anderson, Soil: Genesis \& Geomorphology, Cambridge University Press, 2005, p.390.

6. www.studymode.com, laterite soil by Malaikah 03, June 2013.

7. David, J. Nash, Sue J. McLaren, Geochemical regiments \& Landscapes, John Wiley\& Sons,2011.

8. S. C Agarwal, Satish Chander, Agarwal, History of Indian Fishery, Daya Books, 2006, p.68.

9. Peter Gottschalk, Religion, Science and Empire: Classifying Hinduism \& Ialam in British India, Oxford University Press, 2012. P.162

10. Zaheer Baber, The Science of Empire: Scientific Knowledge, Civilization \& Colonial Rule in India, Sunny Press, 1996.p.150. 
11. Zaheer Baber, op.cit. p. 63.

12. Seyyed Hossein Naser, The Need for a sacred science, Psychology Press, 1995.

13. Peter Gottschalk, Religion, Science \& Empire: Classifying Hinduism \& Islam in British India, oxford University Press, 2012, p.40.

14. Peter Gottschalk, op. cit. p.179.

15. T. Kuhn, The structure of scientific Revolutions (Chicago, 1970.) in Romila, Thapar History and Beyond, oxford University Press,2013.p.89.

16. Romila, Thapar History and Beyond, oxford University Press, 2013. p. 89.12. Ed. by D. K. Silence \& S.S Kadam, Handbook of fruit Science \& Technology: Production, Composition, Storage \& Processing, Marcel Dekker, New York, 1995.

17 . Gordon Johnson, David Arnold, Science, Technology \& Medicine in Colonial India, Vol.3, Cambridge University Press, 2000. P.3

18. Gordon Johnson, David Arnold, Science, Technology \& Medicine in Colonial India, Vol.3, Cambridge University Press, 2000. P.170. 